\title{
MAKING SENSE Of JURISTIC REASONS: UNJUST ENRICHMENT AFTER GARLAND V. CONSUMERS' GAS
}

\author{
MiTCHELL MCINNES
}

This article considers the effect of the recent decision of the Supreme Court of Canada in Garland $v$. Consumers' Gas. The author suggests that lacobucci $J$. 's judgment replaces the traditional common law approach, which relies on the presence of anjust factors, with a unique version of the traditional civil law approach, which relies on the absence of juristic reasons. That decision is criticized as being contrary to precedent and principle. The author then sugges/s how, with slight modifications, the new test of restitutionary liability may be made more workable and coherent.

\begin{abstract}
Cef article examine les effets de la récente décision de la Cour supreme du Canada dans l'affaire Garland c. Consumers' Gas. L'auteur laisse entendre que le jugement de Jacobucci $J$. remplace la démarche sraditionnelle de droit commun reposant sur la présence de facteurs injustes par une version unique de la demarche traditionnelle de droit commun reposant sur l'absence de raisons judicielles. La décision a fait l'objet de critiques comme étant contraire aux précédents et principes. L auteur laisse ensuite entendre de quelle manière, gräce à de légères modifications, le nouveau test de la responsabilite par restitusion peut s'averer plus raisonnable et plus coherent.
\end{abstract}

\section{TABLE OF CONTENTS}

I. INTRODUCTION . . . . . . . . . . . . . . . . . . . . . . . 399

II. UNJUST FACTORS AND JURISTIC REASONS $\ldots \ldots \ldots \ldots \ldots \ldots \ldots \ldots 401$

A. REASONS FOR RESTITUTION $\ldots \ldots \ldots \ldots \ldots \ldots \ldots \ldots \ldots \ldots, 401$

B. PETTKUS V. BECKER ....................... 402

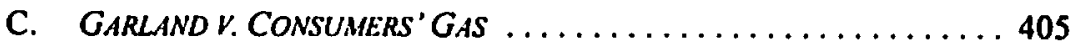

III. THE GaRLAND TeSt ............................ 407

A. SCOPE OF THE TEST $\ldots \ldots \ldots \ldots \ldots \ldots \ldots \ldots \ldots \ldots \ldots, 408$

B. FORMULATION OF THE TEST $\ldots \ldots \ldots \ldots \ldots \ldots \ldots \ldots \ldots, 411$

IV. WRONGDOING AND DISCRETION $\ldots \ldots \ldots \ldots \ldots \ldots \ldots \ldots \ldots \ldots, 422$

A. Strict LIABILITY and FaUlT $\ldots \ldots \ldots \ldots \ldots \ldots \ldots \ldots \ldots, 422$

B. Equitable Discretion ....................... 424

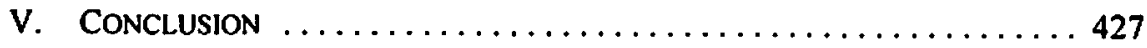

\section{INTRODUCTION}

Private law occasionally requires a dramatic shift in direction. The courts may, for instance, perceive an urgent need to respond to a societal problem that falls outside the scope of established doctrine.' Or they may conclude that an existing body of law is so severely flawed as to necessitate fundamental reconceptualization. ${ }^{2}$

- Currently Associate Professor of Law, Faculty of Law, University of Western Ontario. From I July 2005, Professor of Law, Faculty of Law, University of Alberta. I would like to thank Linda Smits for her meticulous editorial assistance, and the Tremayne-Lloyd Fellowship and the Law Foundation of Ontario for their generous financial assistance.

1 As when the Supreme Court of Canada reformulated the dactrine of constructive trust in order to effect a more equitable distribution of cohabitational assets: Petikus v. Becker, [1980]2 S.C.R. 834 [Petikus]. As when the House of Lords recast the law of negligence under a single principle: Donoghue $v$. Stevenson, [1932] A.C. 562 (H.L.). 
Unless absolutely necessary, however, legal developments are better achieved in small steps. Profound change inevitably creates uncertainty. Because litigants tend to present narrow and skewed perspectives, a judge may, when articulating a new doctrine, act on the basis of incomplete information. ${ }^{3}$ Further, even if a court is presented with a complete picture, it will lack the authority to move much beyond the actual facts. The details will have to be "hammered out on the anvil of concrete cases." And, of course, that process tends to be protracted and painful. Lower courts may disagree on ancillary issues, necessitating repeated trips to the Supreme Court of Canada. At least in the short term, there will be errors and injustice, instability and increased litigation costs.

The recent decision in Garland v. Consumers' Gas" vividly illustrates those concerns. A paradigm has been shifted. Without explanation, and in the absence of any pressing need, the Supreme Court of Canada abandoned the theory of unjust enrichment ${ }^{6}$ that the common law had carefully crafted over the course of several centuries. In its place, the Court imposed a unique test of liability. The law of restitution, never particularly well understood, now faces a period of heightened uncertainty.

The amount of grief that Garland ultimately creates will depend upon the response that it receives.' The case has already been questioned and criticized. ${ }^{8}$ The purpose of this article is more constructive. After sketching the background and summarizing the decision, it suggests how the courts may best move forward. While some of the difficulties associated with Garland are unavoidable, others may be minimized through a simple reorganization of the core concepts.

1 For instance, it seems clear in hindsight that the Supreme Court of Canada went 100 far, 100 fast during a remarkable five month period in 1992 when it substantially expanded the scope of fiduciary obligations in response to a series of sympathetic, though unorthodox, claims: Norberg $v$. Wynrib, [1992] 2 S.C.R. 226; M.(K.) v. M.(H.), [1992] 3 S.C.R. 6; Mcherney v. MacDonald, [1992] 2 S.C.R. 138; see also Hodgkinson v. Simms, [1994] 3 S.C.R. 377. The Court now appears to be somewhat in retreat: K.L.B. v. British Columbia, [2003] 2 S.C.R. 403.

Attorney General v. Blake, [2001] I A.C. 268 at 291 (H.L.).

(2004), 237 D.L.R. (4th) 385 (S.C.C.) [Garland].

"Unjust enrichment" is an ambiguous phrase. It is somutimes used to refer to situations in which the plaintiff, having suffered a breach of obligation (e.g. breach of confidence, trespass to land), forgoes the usual remedy of compensatory damages and seeks instead "restitution" of a benefit that the defendant improperly acquired. Because of the potential for confusion (sce e.g. LAC Minerals Lid. v. International Corona Resources Lid., [1989] 2 S.C.R. 574 [LAC Minerals]), it is best to avoid references to "unjust enrichment" and "restitulion" in such circumstances. The cause of action is not unjust enrichment (as defined below), but rather some form of civil wrong. The remedy is not restitution (as defined below), but rather disgorgement. See L. Smith. "The Province of the L.aw of Restitution" (1992) 71 Can. Bar Rev. 672; Mitctell Mcinnes, "The Measure of Restitution" (2002) 52 U.T.L.J. 163. Early indications are not promising. In the first case to consider Garland, the Court of Queen's Bench in Suskatchewan inexplicably belicved that it was dealing with the "forf of unjust enrichment": Sands v. Erman, [2004] S.J. No. 262 at para. 12 (QL) [emphasis added].

Mitchell Mclnnes, "Unjust Enrichment, Juristic Reasons and Palm Tree Justice: Garlandv, Consumers" Gas Co." 40 Can. Bus. L.J. [forthcoming in 2004]; Mitchell McInnes, "Juristic Reasons and Unjust Factors in the Supreme Court of Canada" (2004) 120 Law Q. Rev. 554. 


\section{UNJUST FACTORS AND JURISTIC REASONS}

Every "civilised system of law is bound to provide remedies for cases of what has been called unjust enrichment."9 And broadly speaking, the operation of the claim is always the same. There is a transfer of wealth between the parties that the law regards as unjust. The invariable response is restitution. The defendant must give the benefit back to the plaintiff.

Within that general scheme, however, there is ample room for disagreement. Every system must answer a series of questions. What counts as an enrichment? Must the plaintiff suffer a loss that corresponds to the defendant's gain? Is restitution available proprietarily? And so on. Different answers reflect different values and different strategies for balancing competing interests, such as the plaintiff's desire to recover a benefit, the defendant's desire for security of receipt and the community's desire for efficient rules.

\section{A. REASONS FOR RESTITUTION}

As a matter of experience, the most significant point of difference concerns the reason for restitution. Assuming that there has been a transfer of wealth, precisely how does a court determine whether or not it is reversible? To simply say that restitution is available for unjust enrichments is obviously inadequate. There must be some means of defining, or at least identifying, injustice. There are two possibilities:

Unjust Factors - The first approach focuses on reasons for reversing enrichments. There must be some positively compelling ground for the court's intervention. Restitution is available only if a transaction is impugned by an unjust factor. Broadly speaking, there are three possibilities. The plaintiff may act with an imperfect intention (for example, by mistakenly paying the same debt twice - the second time in forgetfulness of the first). ${ }^{10}$ The defendant may act unconscientiously (for example, by refusing to pay for a service that he had freely accepted with knowledge of the plaintiff's expectation of remuneration). Or there may be, regardless of the integrity of the plaintiff's intention or the propriety of the defendant's behaviour, some overriding policy factor that demands relief (for example, money paid pursuant to an ultra vires demand that may be recoverable from the government because of the need to respect the constitutional principle prohibiting unauthorized taxation).

" Fibrosa Spolka Akcyjna v. Fairbairn Lauson Combe Barbour Lid., [1943] A.C. 32 at 61 (H.l.).

II The vast majority of restitutionary claims arise from imperfect intentions. That concept encompasses a number of possibilities. The plaintiffs intention may be imperfect because it is: (i) absent, (ii) impaired, or (iii) qualified. The first category includes cases in which the plaintiff is entirely ignorant of the transfer (as when the defendant steals her wallet while she sleeps) or powerless to stop it (as when she helplessly watcles him walk away with it). The second category includes cases in which the plaintiff forms an intention that is not truly a function of her autonomy. The plaintiff may be mistaken (as when she accidentally deposits money into the defendant's account rather than her own). she may suffer un incapacity that prevents her from forming an eflective intention (as when she undertakes a transfer while obviously insane), or her decision may be induced by illegitimate compulsion (as when she confers an entichment under duress). The third category includes cases in which the plaintiff, while fully intending to provide a benefit at the outset, premises the defendant's right to retain that enrichment upon some future fact. If there ultimately is a failure of condition (or, as traditionally phrased, a failure of consideration), the transaction is reversible (as when the plaintiff gives a gift to the defendant in anticipation of a wedding that he later calls off). 
Juristic Reasons - The second approach focuses on reasons for retaining enrichments. The court will intervene unless there is some compelling ground for maintaining the status quo. Restitution is available in the absence of any juristic reason for the transfer. For instance, the plaintiff may have provided a necklace by way of gift or the defendant may have received money in discharge of a debt.

The distinction between those two approaches is profound. The first says "no restitution unless..." while the second says "restitution unless...." Nevertheless, at least in the abstract, there is little to choose as between them. Each carries advantages and disadvantages that reflect its historical origins.

Unjust factors traditionally were employed within the common law and, true to that system's basic orientation, inductively operate from the bottom up. " The specific reasons for restitution evolved, piecemeal and over a prolonged period, on the basis of practical experience. The results of that process cut both ways. Because they are so closely connected to the underlying facts, unjust factors are readily accessible. The layperson easily understands, for instance, why a mistake triggers liability. By the same token, however, the common law's approach to unjust enrichment has been criticized for its inelegance. ${ }^{12}$ In the absence of a single overarching explanation, the grounds for awarding relief tend to be a bit messy.

Juristic reasons, in contrast, traditionally operated within civilian jurisdictions and, true to that system's basic orientation, deductively operate from the top down. At root, there is only ever one reason for restitution: a transfer occurred without legal basis. That single principle then generates specific rules to govern particular cases. Once again, there are merits and demerits. The primary attraction of the classic civilian model is elegance. Essentially the same explanation applies in every case. That elegance is, however, purchased at the cost of abstraction. The idea of an absence of juristic reason is not readily understood. It is easier to comprehend the existence of one thing than the non-existence of many things. Moreover, the civilian model of unjust enrichment appears streamlined only because it delegates much of the work to other areas of law. The restitutionary question is addressed only after it has been determined that, for instance, the plaintiff intended to confer a gift or acted pursuant to a contractual obligation.

\section{B. PETTKUS V. BECKER}

Within Canada, the jurisdictional division between juristic reasons and unjust factors is more complicated than the preceding overview would suggest. Quebec stands somewhat

"There is some danger of overstatement. Especially in recent years, the common law principle of unjust enrichment occasionally exerted an influence from the top down. For instance, in Air Canadav. British Columbia, La Forest J. said that "the judicial development of the law of restitution or unjust ... enrichment renders otiose the distinction between mistakes of fact and mistakes of law" ([1989] 1 S.C.R. 1161 at 1200 [Air Canada], drawing upon Nepean (Township of Hydro Electric Commission v. Ontario Hydro, [ [982] I S.C.R. 347, Dickson J. (as he then was) [Nepean Hydro]). Consequently, the court abandoned the traditional rule in Bilbie $v$. Lumley, which generally denied liability for benefits conferred by mistake of law: (1802), 102 E.R. 448 (K.B.).

12 See e.g. Reinhard Zimmermann, "Unjustified Enrichment: The Modern Civilian Approach" (1995) 15 Oxford J. Legal Stud. 403. 
outside the classic civilian model. While part of its law of unjust enrichment awards relief if a transfer occurred without legal justification, another part operates on the basis of positive reasons for restitution. ${ }^{13}$

The situation in the other provinces and territories is even more complex. Historically, the courts consistently followed the common law approach and determined the availability of relief by reference to unjust factors. The Supreme Court of Canada accordingly premised liability upon proof of mistake, ${ }^{14}$ compulsion, ${ }^{15}$ failure of consideration (qualified intention) ${ }^{16}$ and so on. The waters were, however, muddied when Dickson J. (as he then was) restated the elements of the claim in Pettkus:

[T]here are three requirements to be satisfied before an unjust enrichment can be said to exist: an enrichment, a corresponding deprivation and absence of any juristic reason for the enrichment... The common law has never been willing to compensate a plaintiff on the sole basis that his actions have benefited another.... It must, in addition, be evident that the retention of the benefit would be "unjust" in the circumstances.

That quotation appears to pull in both directions. The traditional common law theory is reflected in the Court's insistence that there must be, in addition to a transfer between the parties, something unjust in the defendant's retention of the benefit. A civilian analysis is suggested by the reference to the absence of any juristic reason for the enrichment. ${ }^{18}$

13 The actio de in rem verso adheres to the civilian tradition by awarding restitution if there is an "absence of justification" for the enrichment that the defendant received from the plaintiff: Cie Immobilière Viger Ltée. v. Lauréat Giguère Inc., [1977] 2 S.C.R. 67 at 77 [Cie Immobilière]. That claim is, however. confined to cases involving services or improvements. Cases concerned with the transfer of property (including money) are governed by the claim for reception de l'indir. And as the Supreme Court of Canada held in Willmor Discouni Corp. v. Vaudreuil (City of), that claim resembles the traditional common law approach insofar as it requires proof of a mistake or compulsion: [1994] 2 S.C.R. 210. The two forms of action are now respectively contained in the Civil Code of Quebec, S.Q. 1991, c. 64, arts. $1493-96$ and art. 1491. See L. Smith, "The Mystery of 'Juristic Reason"” (2000) 12 Sup. Ct. L. Rev. (2d) 211 at 216-17.

14 R. v. Beaver Lamb \& Shearling Co. Lid., [1960] S.C.R. 505; Carleton (County of) v. Otrawa (Ciry of), [1965] S.C.R. 663; Eadie v. Brantford (Township of,, [1967]S.C.R. 573; Breckenridge Speedway Lid. v. Alberia, [1970] S.C.R. 175; Storthoaks (Rural Municipality of) v. Mobil Oil Canada Lid., [1976] 2 S.C.R. 147 [Siorthoaks].

is Stoltze v. Fuller, [1939] S.C.R. 235; Knutson v. Bourkes Syndicate. [1941] S.C.R. 419; Peter Kienrit Sons' v. Eakins Construction Lid., [1960] S.C.R. 36I: George (Porky) Jacobs Enicrprises Lud. v, Regina (City of). [1964] S.C.R. 326.

16. Degiman v. Guaranty Trust Co. of Canada. [1954] S.C.R. 725

11 Supra note 1 at 847.48 .

1* Two years earlier, Dickson J. said, while concurring in Rathwell v. Rathwell, that an unjust enrichment exists if "the facts must display an enrichment, a corresponding deprivation, and the absence of any juristic reason - such as a contract or disposition of lant- for the enrichment" ([1978| 2 S.C.R. 436 at 455 (Rathwell] [emphasis added]). Interestingly, while the highlighted phrase very strongly suggests the civilian analysis, it was not repeated in Pertkus. 
It is not clear why Dickson J. adopted the civilian terminology. ${ }^{19}$ It would be remarkable, however, if he intended to thereby abandon unjust factors in favour of juristic reasons. He relied heavily upon Lord Mansfield's seminal decision in Moses v. Macferlan, ${ }^{20}$ presented the three-part cause of action as the culmination of "general principles ... that have been fashioned by the courts for centuries,"21 and imposed liability on the facts only because the plaintiff had established the unjust factor of free acceptance. To find that Pettkus $v$. Becker nevertheless fundamentally rewrote the law of unjust enrichment, one must accept that Dickson J., without identifying the issue or providing any sort of explanation, was able, through the invocation of a single phrase, to override the great weight of precedent and implant an entirely foreign test at the heart of one of private law's core concepts.

Not surprisingly, few judges were willing to go so far. Although the issue was seldom noticed and never resolved, subsequent courts almost invariably continued to apply the traditional common law approach. The Supreme Court of Canada routinely decided cases on the basis of unjust factors: mistake, ${ }^{22}$ compulsion, ${ }^{23}$ ultra vires demand, ${ }^{24}$ failure of consideration, ${ }^{25}$ free acceptance, ${ }^{26} \mathrm{knowing}$ receipt $\mathrm{t}^{27}$ and so on. Moreover, it typically did so without even referring to the concept of juristic reason.

The debate was, however, kept alive by another, much smaller line of cases in which Dickson J.'s words were literally interpreted and the availability of relief was premised upon the absence of any juristic reason for the defendant's enrichment. ${ }^{28}$ Unfortunately, there was

19 It has been suggested, somewhat ironically in light of later developments, that Dickson J. chose his words in order to stress the need for rules rather than discretion: Garland, supra note 5 at para. 40. The real explanation may be more mundane. The crucial phrase may simply be an accident of bijuridicalism. As explained in the preceding note, Pettkus, supra note 1 , came two years after Rathwell, ibid. That case, in tum, came two ycars after Cie Immobilière, supra note 13, in which Dickson J. sat on an appeal from Quebec dealing with the civilian claim for "unjustified enrichment" (the actio de in rem verso). Justice Beetz's unanimous judgment held that relief was premised upon, inter alia, "the absence of justification" (Cie Immobilière, ibid. at 77). The words may simply have stuck in Dickson J.'s mind. (1760), 97 E.R. 676 at 681 (K.B.) [Moses]. Lord Mansfield stated that the ancient action for moncy had and received (the precursor of most modem restitutionary claims) was available "for money paid by mistake; or upon a consideration which happens to fail; or for money got through imposition (express or implied), or extortion; or oppression; or an undue advantage taken of the plaintiff s situation" (ibid.). Those illustrations all involve reasons for reversing enrichments - i.e. unjust factors.

$21 \quad$ Petkus, supra note 1 at 848.

22 Nepean Hydro, supra nole 11; Canadian Pacific Airlines Lid. v. British Columbia, [1989] 1 S.C.R. I133; Air Canada, supra note II, La Forest J. (relief denied on other grounds).

2. Re Eurig. [1998] 2 S.C.R. 565: but sec Peel (Regional Municipality of] v. Canada, [1992] 3 S.C.R. 762 [Peel].

2. Air Canada, supra note 11, Wilson J.

25 Palachik v. Kiss, [1983] ] S.C.R. 623.

26 Sorochan v. Sorochan, [1986] 2 S.C.R. 38 [Sorochan]: Peter v. Beblow, [1993] I S.C.R. 980, Cory J. [Peter].

27 Citadel General Assurance v. Lloyds Bank Canada, [1997] 3 S.C.R. 805 [Citadel]; Gold v. Rosenberg, [1997] 3 S.C.R. 767 (relief denied on facts).

:A In the Supreme Court of Canada, see Peter, supra note 26. McLachlin J. (as she then was) (in the same case, Cory J. relied upon the unjust factor of tree acceptance); but see Reference re Goods and Services Tax, [1992] 2 S.C.R. 445 |GST Reference]; Nova Scotia (A.G.) v. Walsh, [2002] 4 S.C.R. 325. See also Amertek Inc. v. Canadian Commercial Corp. (2003), 229 D.L.R. (4th) 419 (Ont. Sup. Ct. J.); Garland v. Consumers 'Gas (2001), 57 O.R. (3d) 127 at 147-50, 154.56 (C.A.); Campbell v. Campbell (1999), 43 O.R. (3d) 783 at 790 (C.A.) [Campbell]; Toronto-Dominion Bank v. Carotenuro( (997), 154 D.L.R. (4th) 627 at 636.37 (B.C.C.A.); Allas Cabinets \& Furniture Ltd. v. National Trust (1990), 68 D.L.R. 
never any explanation for that approach and it is difficult to resist the suspicion that, at least occasionally, it arose not so much by design as by a failure to fully investigate the case law surrounding Pettkus.

\section{Garland V. Consumers' Gas}

In practice, then, unjust enrichment was much the same both before and after Pettkus $v$. Becker. The courts generally required positive reasons for intervention. Restitution was premised upon proof of unjust factors. Nevertheless, occasional references to juristic reasons did create a constant threat of incoherence. Though impossible to predict, a judge might award relief simply because there was no basis for the defendant's retention of a benefit. The situation was, as a matter of principle, intolerable. A choice had to be made.

The issue came to a head in Garland. ${ }^{29}$ The defendant sold gas pursuant to pricing schemes approved by the Ontario Energy Board (OEB). Since 1975, those schemes had included a late payment penalty (LPP) of 5 percent of unpaid charges. Although the point was not immediately recognized, the LPPs often contravened s. 347 of the Criminal Code, ${ }^{30}$ which was introduced in 1981 and which prohibited the receipt of interest in excess of 60 percent per annum. ${ }^{31}$ In 1994, the plaintiff, who purchased gas from the defendant and was occasionally neglectful of his account, commenced action for the purpose of attacking the pricing scheme. In 1998, the Supreme Court of Canada agreed that the scheme was illegal. ${ }^{32}$

The plaintiff then proceeded with the restitutionary phase of his claim. Between 1981 and 2001 , the defendant had collected over $\$ 150$ million in LPPs. The plaintiff hoped to recover that money on behalf of himself and a class comprising as many as 500,000 customers. The prospect for success seemed good. In light of the illegality of the pricing scheme, it was hard to see how, notwithstanding the OEB approval, there could be a juristic reason for the enrichment. And in terms of the traditional common law approach, there were several potential unjust factors. While Garland himself had realized the truth of the matter by 1994 , many customers had paid in the mistaken belief that the LPPs were valid. It was also arguable that the LPPs had been paid for a consideration that failed insofar as the customers provided money in discharge of a debt that did not actually exist. Perhaps the simplest solution, however, was based on the illegality itself. ${ }^{33}$ Although precedents are surprisingly sparse, relief ought to be available where the plaintiff, despite being party to an illegal transaction,

(4th) 161 at 172-73 (B.C.C.A.); Re Northern Union Insurance (1984), 33 Man. R. (2d) 81 at 90 (Q.B.), aff d (1985), 36 Man. R. (2d) 115 (C.A.); Duncan v. Duncan (1987), 78 A.R. 171 at 174 (Q.B.); Murray v. Roty (1983), 41 O.R. (2d) 705 at 710 (C.A.).

Supra note 5.

R.S.C. 1970 , c. C-34, as am. S.C. 1980 c. 43 , s. 9.

Because the amount of the L.PP was not tied to the number of days that a bill was overdue, it varied enormously when expressed as an annual interest rate. If a customer waited at least 38 days before paying, the rate fell below 60 pereent per annum. But if payment was missed by a single day, the effective annual interest rate was, by one calculation, a whopping 5.4 billion percent per annum.

Garland v. Consumers' Gas, [1998] 3 S.C.R. 112 [Garland No. 1].

Browning v. Morris (1778), 98 E.R. 1364 (K.B.). But see Kiriri Cotton Co. Lsd. v. Dewani, [1960] A.C. 192 (P.C.) (relief available on basis of mistake of law if plaintiff was not in pari delicto with defendant with respect to illegal transaction). 
was the intended beneficiary of the criminal prohibition and consequently was not in pari delicto with the defendant. ${ }^{34}$

Despite its merits, the claim failed in the lower courts ${ }^{35}$ and only partially succeeded in the Supreme Court of Canada. Writing for a unanimous seven member panel, ${ }^{36}$ lacobucci $J$. imposed liability on the basis of a new two-part test of liability:

First Branch - The plaintiff must prove that the facts do not fall within one of the "established categories" of juristic reason: contract, disposition of law, donative intent or "other valid common law, equitable or statutory obligations." 37 If that burden is discharged, restitution prima facie is available.

Second Branch - The defendant then becomes subject to a de facto burden of proof to show some other reason as to why the enrichment should be retained. Two considerations are particularly important at that stage: public policy and the parties' reasonable expectations.

With respect to the first branch, lacobucci J. focused on the fact that a benefit received by right of statute is irrecoverable ${ }^{38}$ by virtue of being a "disposition of law." ${ }^{39}$ That analysis did not, however, apply on the facts. Although the LPPs had received approval under the Ontario Energy Board Act, ${ }^{40}$ the provincially-approved scheme contravened s. 347 of the Criminal Code. The doctrine of constitutional paramountcy consequently rendered the OEB rate orders inoperative to the extent of the conflict. Restitution prima facie was available.

The second branch was more complicated. On the question of public policy, lacobucci J. cited the basic proposition that "a criminal should not be permitted to keep the proceeds of their crime." And on the question of reasonable expectations, he held that the defendant's

For instance, regardless of any mistake, a tenant may be able to recover "key money" that had been illegally paid to a landlord in order to secure a lease: Gray v. Southouse, [1949] 2 All E.R. 1019 (K.B.). See also Schellenberg v. Ely Canada Lid., [1962] O.J. No. 195 (H.C.J.) (QL); Jeffrey v. Fitzroy Collingwood Rental Housing Association, [1999] V.S.C. 33 at para. 44.

The trial judge dismissed the claim on the basis that it constituted an impermissible collateral attack on the OEB orders: Garland v. Consumers ' Gas (2000), 185 D.L.R. (4th) 536 (Ont. Sup. Ct. J). The Ontario Court of Appeal unanimously rejected that reason, but by a majority upheld the sesult (supra note 28 at para. 70). Chief Justice McMurtry (MacPherson J.A. concurring) held, inter alia, that it would be "contrary to the equities" to order restitution because the defendant had acted pursuant to OEB orders (which had not been directly attacked) and because the burden of liability would ultimately fall upon the defendant's customer base as a whole. Justice Borins dissented. After reviewing, but not attempting to resolve, the debate as between unjust factors and juristic reasons, he applied the latter and held that the decision in Garland No. 1, supra note 32, had deprived the OEB order of effect and consequently could not provide a juristic reason for the enrichment. Given the extent to which Petskus, supra note 1, may have reflected a civilian influence, it is interesting to observe that four of the seven judges in Garland have largely, if not exclusively, civilian backgrounds: Bastarache, LeBel, Deschamps and Fish IJ. Garland, supra note 5 at pasa. 44.

GST Reference, supra note 28; Mack v. Canada (A.G.) (2002), 60 O.R. (3d) 737 (C.A.).

Justice lacobucci did not address the fact that the LPP payments were made pursuant to valid and subsisting contracts.

4.) S.O. 1998, c. 0-15.

"Garland, supra note 5 at para. 57. 
customers must have anticipated being subject to some penalty for late payment, just as the defendant legitimately assumed that the OEB would not approve an illegal scheme. The cumulative effect of those considerations was to substantially curtail the plaintiff's right to relief. First, the defendant was entirely immune from liability with respect to payments received before 1994, when the plaintiff commenced his action. Because there was no reason prior to that time for the defendant to suspect that anything was wrong, its "reliance on the inoperative OEB orders provide[d] a juristic reason for the enrichment." 42 Second, with respect to payments received after the issue had come to light, "the reasonable expectation of the parties ... [was] achieved by restricting the LPPs to the limit prescribed by s. 347 of the Criminal Code." In other words, the late payment penalties were, regardless of the defendant's knowledge, valid and irrecoverable to the extent that they fell below 60 percent per annum. ${ }^{4}$ Consequently, the defendant was, notwithstanding the general principle of public policy, allowed to retain millions of dollars that it had illegally extracted from its customers.

\section{TIE GARLAND TEST}

Garland raises a number of concerns. The most fundamental problem stems from Iacobucci J.'s decision to devise a "distinctive Canadian approach," rather than reaffirm the traditional common law analysis or adopt the classic civilian model. As previously explained, the great attraction of unjust factors is accessibility, while the appeal of juristic reasons is elegance. Garland unfortunately leaves Canada with "the worst of both worlds, more abstraction, unintelligible to the lay litigant, without the elegant automation that is supposed to be bought at that price." operates on the basis of juristic reasons, abandons unjust factors and with them the hope of easy comprehension. The open-ended nature of the second branch, which allows the defendant to adduce proof of any other reason for an enrichment, eliminates the simplicity of the classic civilian model.

For present purposes, however, the more significant concerns pertain to the precise formulation of the test. And to a large extent, those difficulties are attributable to Garland's surprising lack of substance. While recognizing the existence of the debate regarding unjust factors and juristic reasons, lacobucci J. did little more than express a preference for the latter and sketch a new test of recovery. His judgment failed to identify, let alone resolve, the profound issues associated with the shift from the common law to the civilian model of liability. Contrary to precedent, he apparently assumed that Canadian law had already adopted a juristic reason analysis in both name and substance, and consequently saw his task as merely one of "redefinition and reformulation." But even if the underlying assumption

Jbid. at para. 58.

Jbid. al para. 55 .

Transport North American Express Inc. v. Nen' Solusions Financial Corp., [2004] I S.C.R. 249.

Supra nute 5 at para. 42. Justice lacobucci's decision on point is, in fact, ambiguous. Despite his comments regarding the parties' reasonable expectations, he ultimately held, in the final paragraph of his judgment, that the defendant would be liable "in an amount determined by the trial judge" (Ibid. at para. 91).

Peter Birks, "Mistakes of Law" (2000) 53 Curr. Legal Probs. 205 at 232. Although Birks wrote prior to Garland, lacobucci J.'s decision exacerbated the dificulties that motivated that assessment.

Garland, supra note 5 at para. 44. 
had been correct, it could not explain why the judgment proceeded in such broad strokes. Given the novelty of the new test and the infrequency with which the Supreme Court of Canada hears appeals in the area, lower courts are in need of much more guidance.

\section{A. SCOPE OF THE TEST}

The first question arising from Garland concerns the scope of lacobucci J.'s new two-part test. Does it govern every claim for restitution? Or is it somehow confined to certain types of cases?

There will be a strong pull toward the latter approach. Notwithstanding Dickson J.'s choice of words in Pettkus, lawyers in this country have little experience with juristic reasons. Consequently, in the interests of clarity and continuity, there will be a temptation to marginalize Garland and, whenever possible, to adhere to the traditional unjust factors. That is particularly true in the context of commonly encountered claims. In the paradigm case of mistaken payment, for example, it will be difficult to overcome the habit of awarding relief on the basis of the plaintiff s impaired intention, and instead resolve the dispute by reference to the transfer's lack of purpose.

That temptation must nevertheless be resisted. In contrast to Pettkus, Garland unequivocally adopted a civilian model. Whereas Dickson J. said one thing but did another, Iacobucci J. was consistent in word and action. It is no longer possible to deny that juristic reasons are legitimately part of the Canadian law of unjust enrichment.

Nor is it possible, as a matter of precedent or principle, to artificially confine that approach to certain categories of claim. While lacobucci J. did not expressly address the issue, nothing in his judgment admits of exception. The most natural interpretation of Garland is that the new two-part test applies across the board. Moreover, it is absolutely imperative for Canadian courts to avoid the sort of inconsistency that followed Pettkus. In a perfect world, Garland would have gone the other way and lacobucci J. would have reaffirmed the Canadian commitment to unjust factors. Far worse than the difficulties created by the move to juristic reasons, however, are the difficulties associated with the coexistence of two fundamentally different conceptions of unjust enrichment. Such inconsistency is not merely an intellectual embarrassment, but also a potential source of confusion and injustice.

\section{l. LIMITED RECONCILIATION}

That is not to say, however, that the traditional precedents have become irrelevant. They will, of course, continue to apply with full force to issues that are not affected by the shift from unjust factors to juristic reasons. The identification of enrichments and deprivations is, for instance, independent of the precise reasons for restitution. But even on the narrow question of "injustice," the old cases will often remain important.

Take a simple example: A woman gives $\$ 500$ to her nephew as a birthday present. The next day, forgetting what she already had done, she gives another $\$ 500$ for the same purpose. When she eventually discovers the oversight, she demands restitution. The validity of her claim can be expressed at three different levels of abstraction: 
Statement of Conclusion - At the highest level of abstraction, relief is available simply because the transfer was unjust and hence reversible. Of course, given its extreme generality, that statement cannot serve as an actual test of liability. It requires something more specific - an explanation as to why the transfer was unjust.

Absence of Juristic Reason - At the intermediate level, relief is available because there was an absence of juristic reason for the defendant's enrichment. The purpose underlying the transfer failed. The plaintiff provided the second payment in satisfaction of a donative intent that had already been fulfilled. The civilian model operates at that level. Significantly, however, it too requires something more specific - an explanation as to why the transfer's intended purpose failed.

Unjust Factor - At the lowest level of abstraction, relief is available because the plaintiff was mistaken. That error vitiated the intention to give and destroyed the transfer's apparent basis. The traditional common law model operates at that level. Although further distinctions historically were drawn, the prevailing modern view denies the need for a more specific explanation. ${ }^{48}$

The example illustrates what Birks calls the "limited reconciliation" of the juristic reasons and unjust factors. ${ }^{49}$ In most cases, the plaintiff will have conferred the enrichment for a particular purpose: the provision of a gift, the fulfillment of a contractual obligation, the satisfaction of a statutory duty and so on. Like the classic civilian model, Garland awards relief because that intended purpose failed. In reaching that conclusion, however, it necessarily relies on the considerations that traditionally served as unjust factors. There must be some explanation as to why the plaintiff did not achieve her goal. The purpose of the gift failed because the donor mistakenly overlooked the fact that she had already given a present. The purpose of fulfilling a contractual obligation may fail because the apparent agreement was invalidated by the recipient's compulsion. The purpose of satisfying a statutory duty may fail because the government's demand was ultra vires. And so on.

That reconciliation ought to run even deeper. Garland's absence of juristic reason necessarily builds upon the types of consideration that historically served as unjust factors. Significantly, however, it is not enough to say in the abstract that a benefit was triggered by, say, "mistake" or "compulsion" or "ultra vires demand." Those concepts require definition, not only for the purpose of practical application but also for the purpose of balancing competing interests. "Compulsion," for instance, does more than provide a label for invalidated agreements. It also constitutes a concept that mediates a sensitive compromise

4h The plaintiff sometimes was required to prove a particular type of mistake (e.g. a "liability" mistake or a mistake "as between the parties"). The modern view. however, is that any causative mistake is sufficient to vitiale a beneficial intention: Air Canada, supra note II at I191: Central Guaranny Trust v. Dixdale Mortgage Imestment Corp. (1994), 24 O.R. (3d) 506 at 512 (C. A.) [Dixclake): Nleinwort Benson Lid. v. Lincoln City Council, [1999] 2 A.C. 349 at 372, 399, 407-408 (II.L.): Banque Fintancière de la Ciné v. Parc (Battersea) Lid., [1999] I A.C. 221 at 227. 234 (H.L.) [Battersea]; David Securities Pty. Lid. v. Commonwealth Bank of Australia (1992), 175 C.L.R. 353 at $376-78$ (H.C.A.).

4* Peter Birks, Unjust Enrichment (Oxford: Oxford University l'ress, 2003) at 101. ("A pyramid can be constnucted in which, at the base, the particular unjust factors such as mistake, pressure, and undue influence become reasons why, higher up, there is no basis for the defendant's acquisition, which is then the master reason why, still higher up, the enrichment is unjust and must be surrendered"). 
between the plaintiff's desire to be free from illegitimate pressure, the defendant's desire to exploit a superior bargaining position, society's desire for the enforcement of contracts and so on. Having set themselves the daunting task of shifting from a common law model of liability to one of civilian inspiration, Canadian courts must maintain some connections to the past. The logic of Garland may, in exceptional circumstances, require underlying principles to be revisited. In most instances, however, the absence of any juristic reason for an enrichment will be best explained by reference to the tests that have been carefully crafted, over many years, as unjust factors.

At the same time, however, it is important for Canadian judges to recognize that the possibility for reconciliation is limited and that some cases will fall outside the preceding pattern of analysis. In such circumstances, the traditional unjust factors will provide little, if any, guidance. The relevant cases will tend to fall into two groups.

The first group of cases lying outside the area of reconciliation involves enrichments that did not arise through the failure of purposive transfers. In some situations, the gist of the plaintiff's complaint is not "I didn't really intend that result," but rather "I didn't intend anything at all." The defendant may have found the plaintiff's wallet, or stolen it while she slept, or brazenly taken it while she helplessly watched from afar. This is one area where the juristic reason approach may be an improvement. While Garland was designed primarily to deal with failed purposes (such as the giving of gifts and the fulfillment of obligations), a claim based on a complete absence of purpose is a fortiori. There undoubtedly is an absence of any juristic reason for an enrichment that was found or stolen. The traditional common law approach, in contrast, often struggled with such claims. In the leading case on stolen money, the House of Lords notoriously failed to specify an unjust factor. ${ }^{50}$ And in the leading case on misdirected trust funds, the Supreme Court of Canada required not only proof of the beneficiary's imperfect intention but also, quite improperly, proof of the recipient's wrongdoing."

The second group of cases falling outside the standard pattern of reconciliation is more complicated. While acting purposively, the plaintiff may have conferred an enrichment upon the defendant in circumstances that do not raise an unjust factor, but which nevertheless prima facie trigger relief under the new juristic reason analysis. Because the claim never would have gotten off the ground under the traditional common law approach, the lack of precedent will make it difficult for the court to convincingly reach a conclusion.

That problem is most likely to arise in connection with unsolicited and non-obligatory benefits that the plaintiff knowingly provided with the intention of demanding repayment. An example can be borrowed from Birks. ${ }^{32}$ The plaintiff, who lives below the defendant in a poorly insulated apartment building, spent a small fortune heating her unit during a long winter. The defendant took advantage of the laws of convection and was saved the expense of heating his unit. Is the plaintiff entitled to restitution for that enrichment? 
The answer is obvious on the traditional common law approach. There is no unjust factor. The plaintiff did not, for instance, labour under a mistake or illegitimate pressure. The result must also be the same under Garland, but the explanation is far from clear. Since there was no obligation involved, the plaintiff prima facie will be entitled to recover upon disproof of a donative intent: ${ }^{53}$ The defendant will likely respond by arguing: (i) that a restitutionary enrichment must be "more than an incidental blow-by," "s4 and (ii) that relief is not available with respect to actions taken in self-interest. Significantly, however, since the idea of a "collateral benefit" was largely irrelevant under the traditional common law scheme, it has not been "much discussed by ... authorities to date"ss and, in any event, may be "too imprecise" 56 for application. Nor did the common law courts find it necessary to develop a comprehensive scheme regarding enrichments incidentally arising from the plaintiff's own self-interest. Depending upon the existence of an independent unjust factor, restitution was both allowed ${ }^{57}$ and denied..$^{58}$

\section{B. FORMULATION OF THE TEST}

Moving from the general to the particular, a number of issues arise with respect to the precise formulation of the Garland test. They can be broken down according to whether they pertain to: (i) the division of juristic reasons; (ii) considerations arising under the first branch; and (iii) considerations arising under the second branch.

\section{THE DIVISION OF JURISTIC REASONS}

The division of juristic reasons within Garland calls for comment on two fronts.

\section{a. Branches of Juristic Reasons}

Once the court is satisfied of an enrichment and a corresponding deprivation, it must determine whether there was an absence of any juristic reason for the transfer. Prior to Garland, some commentators argued against the adoption of a civilian model of liability on the ground that, while the common law generally requires the plaintiff to prove every element of a claim, it would be impossible for a claimant to disprove every conceivable reason for an enrichment. There are simply too many possibilities." Justice lacobucci responded to that concern by "closing the list of categories that the plaintiff must canvass." branch of his test, the plaintiff must show that a benefit was not provided as a gift, pursuant to a disposition of law, in fulfillment of a contractual obligation or as satisfaction of "other

In Unjust Enrichment, ibid. at 141, Birks argues that the enrichment must be regarded as a "grudging giff," but that simply assumes the problem away. However unusual, the plaintilf. perlaaps resentful of the defendant's free ride, may have intended from the outset to charge for the benefit.

Ibid.

G. Jones, ed., Goff \& Jones: The Lanr of Restitufion. 6th ed. (London: Sweet \& Maxwell, 2002) at 65 Exall v. Partridge (1799), 10। E.R. 1405 (K.B.).

Ruabon Steamship v. London Assurance, [1900] A.C. 6 at 12 (H.L.): Ulmer v. Farnsworth I5 A. 65 (Me. 1888).

Smith, "The Mystery of 'Juristic Reason," stupra note 13 at 228.

Garland, supra note 5 at 44. 
valid common law, equitable or statutory obligations." If that burden is discharged, restitution prima facie is available and the defendant becomes subject to a "de facto burden of proof" to rebut the prima facie claim by establishing "another reason to deny recovery."

The resulting scheme is somewhat arbitrary. The heart of any juristic reason analysis must consist of the failure of a purposive transfer. Relief is available because the plaintiff tried, but failed, to achieve a certain purpose. Garland's first branch, however, encompasses most, but not all, possible purposes. For instance, while the plaintiff bears the burden of proving that a benefit was not provided either as a gift or in satisfaction of some sort of legal obligation, the defendant apparently is responsible for demonstrating that the enrichment was conferred in satisfaction of a natural obligation. ${ }^{63}$ Moreover, Garland's second branch allows the defendant to defeat a claim by showing either that the transfer fulfilled certain goals (such as satisfaction of a natural obligation) or that, even though the enrichment did not occur for any good reason, there is some other basis for denying relief.

\section{b. Juristic Reasons and Defences}

Those problems are further exacerbated by the relationship that exists between the test of liability and the various categories of defence. Garland itself is illustrative. Within the threepart cause of action, the plaintiff established a prima facie right to relief that the defendant partially rebutted by means of a juristic reason. Justice lacobucci then went on, purportedly in a separate (fourth) stage of analysis, to consider several "defences." Curiously, however, most of those defences involved precisely the same sort of considerations that he had previously addressed in connection with juristic reasons. While change of position was immediately recognizable as a traditional defence, the defendant also unsuccessfully argued that certain statutory provisions precluded liability, that the OEB orders could not be undermined by a collateral attack and that the collection of LPPs was analogous to government action made under colour of authority.

Justice lacobucci offered no explanation as to the difference between juristic reasons and defences. ${ }^{64}$ To the contrary, he appeared to equate the two. He referred to the second branch

\section{lbid.}

Ibid. at para. 45.

That is, an obligation that, while juridically unen forceable, was binding upon the plaintiff in conscience or morality. The concept of natural obligations undoubledly exists under the traditional common law approach. In Moses v. Macferlan, Lord Mansfield said that restitution "does not lic for money paid by the plaintiff, which is claimed of him as payable in point of honor and honesty, although it could not have been recovered from him by any course of law; as in payment of a debt barred by the Statute of Limisations, or contracted during his infancy, or to the extent of principal and legal interest upon an usurious contract, or, for money fairly lost at play: because in all these cases, the defendant may retain it with a safe conscience, though by positive law he was barred from recovering" (supra note 20 at 68081). Natural obligations nevertheless have had little impact within the common law. A claim defealed by reason of a natural obligation is apt to fail in any event for want of an unjust factor. In contrast, because a juristic reason model prima facie imposes liability for every unwarranted transfer, some claims will be properly defeated only upon proof of the plaintif's natural obligation. See generally" Duncan Shechan, "Natural Obligations in English Law" [2004] L.M.C.L.Q. 172.

There is, of course, no need for a similar explanation under the traditional common law approach. Unjust factors and defences unequivocally point in opposite directions. One provides reasons for allowing recovery: the other provides reasons for denying relief. 
of the juristic reason analysis as a "residual category of defence," and directed the courts are to "look to all of the circumstances of the transaction in order to determine whether there is another reason to deny recovery." ${ }^{\text {"Ss }}$ That is almost precisely the same exercise that he proposed in connection with the defence of change of position. ${ }^{66}$

Consequently, on a literal interpretation of Garland, it may be difficult to predict how a particular argument will be characterized. If, on the facts of Garland, a statutory provision had immunized any money that the defendant received under the apparent authority of an OEB rate order, would the plaintiff's payment have been irrecoverable: (i) because it had been paid in satisfaction of a "disposition of law" under the first branch of lacobucci J.'s test, or rather (ii) because of the operation of an independent defence? In another context, would officiousness constitute: (i) a residual category of juristic reason under the second branch of lacobucci J.'s test, ${ }^{67}$ or rather (ii) a free-standing defence? The examples are easily multiplied.

That uncertainty creates difficulties on a number of levels. Whenever an argument may be plausibly characterized as either an "established category" of juristic reason or a defence, it will be unclear as to whether the burden of proof falls upon the plaintiff or the defendant. And even if the choice lies between a residual category of juristic reason and a defence, such that the onus undoubtedly falls upon the defendant, the proper characterization may be important for the purposes of pleading. Leaving aside issues that may arise in the actual conduct of a case, Garland's division of labour also creates significant obstacles to exposition and comprehension. How are the various principles to be organized and explained?

\section{c. A Modest Reformulation}

Literally interpreted, Garland will not work. Its constituent parts are inadequately defined and insufficiently distinguished. Significant improvements can, however, be achieved through a modest reformulation. The following proposal changes nothing of substance. It simply clarifies the core concepts and organizes them in a more coherent manner. Ironically, in doing so, it better reflects the court's desire for a two-tier analysis in which the plaintiff establishes a prima facie claim and the defendant establishes residual reasons for denying relief.

The proposal is modest in another sense as well. Unjust enrichment is a large and difficult area, especially after Garland. A proper exploration of the emerging approach will require a full book. This article is far less ambitious. It merely sketches the new restitutionary landscape, fixing its borders and identifying its principal features. It does not attempt to fill in every detail.

(1) Perhaps because there is a policy against intermeddling; perhaps because reasonable people do not expect liabilities to arise from unsolicited interventions. 
(i) The Plaintiff's Arguments

Following the general presumption of private law, the claimant must prove the entire cause of action. Accordingly, having demonstrated an enrichment and a corresponding deprivation, she must show that there was, prima facie, an absence of any juristic reason for the transfer. Such proof will take one of two forms:

No Purposive Transfer - The simpler cases involve transfers that, from the plaintiff's perspective, were not purposive. For example, the defendant may have found an asset that had been lost, or received an enrichment that had been stolen. In such circumstances, there obviously is an absence of any juristic reason for the enrichment.

Failure of a Purposive Transfer - The more complicated cases involve transfers that, from the plaintiff's perspective, were purposive (such as the provision of a gift or the performance of a contract). Since those purposes presumptively constitute juristic reasons for the defendant's enrichment, the plaintiff must demonstrate that they somehow failed. Such proof will involve considerations that historically served as unjust factors (such as mistake, compulsion or incapacity).

The third element of the action in unjust enrichment therefore consists largely of lacobucci J.'s first branch of juristic reasons. It is, however, somewhat broader. It more clearly encompasses cases in which the plaintiff did not act purposively. And it includes cases in which the plaintiff unsuccessfully acted in fulfillment of a purpose (for example, a natural obligation $^{68}$ ) not enumerated in Garland's "established categories."

\section{The Defendant's Arguments}

Faced with a restitutionary action, the defendant may escape or reduce liability in two ways:

Avoidance of Prima Facie Claim - The defendant may be able to undermine the plaintiff's effort to demonstrate a prima facie claim. Some arguments will fall outside the scope of the current discussion. For instance, while acknowledging the receipt of an objective benefit, the defendant may plead subjective devaluation and convince the court that recognition of an enrichment would intolerably override his freedom of choice. ${ }^{69}$ More significantly for present purposes, the defendant may focus on juristic reasons. If the plaintiff baldly denies that there was any basis for the transfer, the defendant may point to a purpose for which the benefit was conferred. ${ }^{70}$ And if the plaintiff concedes the existence of an

As defined and explained in supra note 63.

(1") Mitchell Mclnnes, "Enrichments and Reasons for Restitution: Protecting Freedom of Choice" (2003) 48 McGill L.J. 419 [McInnes, "Enrichment and Reasons for Restitituion"].

"It is oflen obvious which justifications are in play. Occasionally, however, possibilities may be overlooked. In Garland, supra note 5, Jacobucci J. asked whether the enrichments were received pursuant to a disposition of law, but did not further consider the fact that they had been paid in satisfaction of contractual obligations. 
apparent justification, but argues that it was in fact ineffective, the defendant may persuade the court otherwise."

Independent Defence - If the plaintiff succeeds in establishing a prima facie right to restitution, a burden will fall upon the defendant to show that, even though the transfer did not fulfill an intended purpose, recovery ought to be refused or reduced on the basis of a defence. Some defences tie back into the prima facie claim. For instance, the defence of passing on demonstrates that the plaintiff did not truly suffer a corresponding deprivation, just as the defence of change of position should operate by showing that the defendant suffered a dis-enrichment. ${ }^{72}$ Other defences are more independent of the constituent elements of the claim. The court may be convinced, for instance, that there was something in the plaintiff's conduct (officiousness, self-interest, illegality) that precludes recovery. Alternatively, the defendant may point to some extraneous policy, such as a limitation period, that would be frustrated by the imposition of liability.

\section{THE FIRST BRANCH}

The preceding reformulation helps to resolve an issue arising from Garland. The first branch of lacobucci J.'s test requires the plaintiff to show that the transfer did not fall within one of the "established categories" of juristic reason. The second branch of that test then allows the defendant to persuade "the court ... that a new category of juristic reason is established." $\mathrm{A}$ question immediately arises as to the relationship between those two branches. Does the establishment of "a new category of juristic reason" by the defendant constitute a new "established category" of juristic reason for which the plaintiff will bear responsibility in future cases? Although lacobucci J. did not address that issue, the answer must be in the affirmative if, but only if, the "new category" consists of some form of purposive transfer. The plaintiff should be responsible for demonstrating that the enrichment was made either without purpose or for a purpose that failed. The defendant should be responsible for demonstrating that there is nevertheless some reason for denying relief.

" For instance, if the plaintiff argues that an apparent gift was the product of an impaired intention, the defendant may persuade the court that the purported mistake was legally ineffective (e.g. because the plaintifr, while lacking complete information, knowingly chose to assume the risk of error).

12

There are two models of change of position. The tirst involves the concept of disenrichment. The defendant will not be considered initially enriched unless he received a benefit for which he chose to accept financial responsibility or for which there was no choice to make. Nor will he be considered ultimately enriched if, before learning of the plaintifr's claim, he incurred an expenditure that he would not have chosen if he had known of his impending liability. The essence of the dis-enrichment model is that restitution should never create a hardship by overriding the recipient's freedom of choice: Mclnnes, "Enrichments and Reasons for Restitution," supra note 69.

The second model of change of position operates very loosely on the basis of "cquity" and "justice." Recovery is reduced to the extent that the court belicves, in light of the defendant's exceptional expenditure and all of the other circumstances, that liability would be unfair. The obvious difficulties with that approach recently led the Privy Council to reject it as being "hopelessly unstable": Dexira Bank \& Trust Co. Lid. v. Bank of Jamaica. [2002] I All İ.R. (Comm.) 193 (P.C.) [Dexira Bank]: bul see Jones v. Commerzbank A.G., [2003] E.W.C.A. Civ. 1663 (C.A.).

Unfortunately, while the facts of Garland did not require the defence to be considered "in a comprehensive manner," Iacobucci J. preferred the second model (supra note 5 at para. 66). The issue needs to be revisited. 
The other significant issue arising from the first branch of the Garland test concerns the scope and definition of the "established categories." Indeed, those are the largest questions that the courts will eventually have to answer. It may be some time before a detailed picture emerges. For present purposes, an outline must suffice.

Donative Intent - While this category will inevitably focus on the intention to provide outright gifts, it must also include other forms of gratuitous transfers, such as the voluntary settlement of an express trust and the abandonment of property.

Contract - Although the relationship between unjust enrichment and contract is in many respects contentious, the basic idea is reasonably straightforward. For fear of upsetting bargains and reallocating risks, restitution is not available with respect to benefits governed by agreements. That proposition traditionally required the plaintiff to show that the contract was invalid, discharged for breach or unenforceable. In recent years, however, there has been a greater willingness to allow recovery within a subsisting, enforceable agreement, as long as the risk associated with the impugned benefit was not assigned to either party. ${ }^{74}$ That practice has been called into question. ${ }^{\text {ts }}$

Disposition of Law - It is clear from Garland itself that a transfer occurring under statutory authority may be irrecoverable as a "disposition of law." A benefit conferred in satisfaction of a judgment that has not been overturned is presumably caught as well. Beyond that, however, the scope of this category remains unsettled.

Other Valid Common Law, Equitable and Statutory Obligations - Justice lacobucci's fourth "established category" is really not so much a category as a catch-all. And as is typical of a miscellany, it suffers from being over-inclusive, under-inclusive and imprecise. The reference to "statutory obligations" is redundant of the separate category of "disposition of law." The focus on various forms of legal obligation excludes cases involving other types of obligations (such as natural obligations ${ }^{76}$ ). And finally, it is difficult to enumerate the legal obligations that remain after those arising from contracts and "dispositions of law" have been removed to other categories. That list will include obligations as disparate as a trustee's duty to distribute trust assets and a parent's non-statutory duty to provide necessities of life to a child.

Garland, ibid, is a case in point. Justice lacobucci failed to address the fact that the LPPs were received pursuant to contracts that had never been invalidated. See also Raxborough v. Rothmans of Pall Mall Ausiralia Led. (2001), 208 C.L.R. S16 (H.C.A.) [Roxborough].

" Robert Chambers, "Canada" [2004] R.L.R. 182; Birks, Unjust Enrichment, supra note 49 at 107-10: Peter Birks, "Failure of Consideration and Its Place on the Map" (2002) 2 Oxford U. Commonwealth I.J. 1: J. Beatson \& Graham Virgo, "Contract, Unjust Enrichment and Unconscionability" (2002) 118 Law Q. Rev. 352: M. Bryan, "Unjust Enrichment and Unconscionability in Australia: A False Dichotomy?" in Jason W. Neyers, Mitchell Mcinnes \& Stephen G.A. Pitel, eds., Understanding Unjust Enrichment (Oxford: Hart, 2004) 47. J.W. Carter \& G.J. Tolhurst, "Case Comment: Roxborough v. Rothmans of Pall Mall" (2003) 19 J. Cont. L. 287.

7. As discussed at supra note 63. 


\section{THE SECOND BRANCH}

As previously discussed, Garland's second branch must be dismantled and its contents redistributed. Considerations pertaining to the existence and fulfillment of purposive transfers must be shifted into the first branch. ${ }^{77}$ All other considerations must be shifted out of the three-part cause of action and into a fourth stage of analysis dealing with defences.

Problems then arise with respect to the nature of those defences. The action in unjust enrichment will become unworkable if the courts literally interpret lacobucci J.'s invitation to "look to all of the circumstances of the transaction in order to determine whether there is another reason to deny recovery." While the resolution of a restitutionary claim undoubtedly requires an examination of "all of the circumstances," there will be little prospect for consistent and principled results unless the various aspects of each transaction are isolated and addressed within the context of specific concerns.

Somewhat more promisingly, lacobucci J. also said that, "[a]s part of the defendant's attempt to rebut" the plaintiff's prima facie case, the "courts should have regard to two factors: the reasonable expectations of the parties, and public policy considerations." ${ }^{\text {" Upon }}$ closer examination, however, that proposition raises much the same concern. Unless refined, the concepts of "reasonable expectations" and "public policy" are hopelessly open-ended and may, depending upon a judge's interpretation, encompass virtually any issue.

\section{a. Public Policy}

Under the traditional common law approach, "public policy" served as a category of unjust factor. Significantly, however, restitution could not be claimed on the basis of public policy per se. The plaintiff had to frame the claim with much greater specificity. That can be seen, for instance, in the claim for money paid pursuant to an ultra vires demand ${ }^{80}$ The reason for restitution did not consist of the vague sense that, when in doubt, a court should prefer a taxpayer to a public authority. It was, rather, firmly rooted in the policy of respecting the constitutional principle that prohibits a government from extracting money without a mandate. $^{81}$

Likewise in the present context. "Public policy," without more, is meaningless. At some level, every decision reflects the judge's perception of public policy. Worse yet, the concept may be construed as a license to dispense palm tree justice. Consequently, when applied to individual cases, policy must be expressed in terms of specific principles. In Garland, for

To reiterate, the plaintiff must bear the ultimate burden of proof with respect to such considerations. Depending on the circumstances, an evidentiary burden may fall upon the defendant.

7k Garland, supra note 5 at para. 45

74 Ibid. at para. 46. A question may arise as to whether reasonable expectations and public policy are the only the relevant considerations. There is, however, no reason in principle why the inquiry should be so restricted, and lacobucci J. "s broader comments regarding "all of the circumslances" point the other way.

Woohrich Equilable Building Socieby v. Inland Revenue Commssion (No. 2), [1993] A.C. 70 (H.1.) [Woohwich]: Air Canada, supra note II, Wilson J., but see la Forest J.

"t Peter Birks, "Restitution lirom the Executive: A Tercentenary Footnote to the Bill of Rights" in l'aul D. Finn. ed., Essajs on Restitution (Sydney: Law Book Co.. 1990) 164. 
instance, Iacobucci J. invoked the "overriding public policy" that "a criminal should not be permitted to keep the proceeds of their crime." ${ }^{82}$ Canadian courts will also need to work out, in detail, a policy that denies relief to the officious meddler, ${ }^{83}$ a policy that precludes recovery for benefits that the claimant incidentally conferred while acting in the pursuit of self-interest ${ }^{84}$ a policy that prevents voluntary transactions from being reopened, ${ }^{85}$ a policy that prohibits the action in unjust enrichment from being used to circumvent certain forms of contractual incapacity, ${ }^{86}$ and so on.

\section{b. Reasonable Expectations}

In addition to public policy considerations, lacobucci J. directed courts to have regard to "the reasonable expectations of the parties." That is a worrying proposition.

\section{Problems in Precedent and Principle}

Though not cited as such, the references to the parties' expectations, like other parts of Iacobucci J.'s test, ${ }^{87}$ are derived from the earlier decision in Peter. In that case, McLachlin $\mathrm{J}$. (as she then was) said that "[i]n every case, the fundamental concern is the legitimate expectation of the parties." ${ }^{188}$ She based that rather surprising statement on her reading of Pettkus. And true enough, Dickson J. (as he then was) had awarded relief on the ground that the defendant received his enrichment with (constructive) knowledge that the plaintiff "prejudice[d] herself in the reasonable expectation" of receiving an interest in the cohabitational home. ${ }^{89}$ Significantly, however, there is nothing in Pettkus to suggest that the parties' "legitimate expectation" is "fundamental," or even relevant, in "every case." To the contrary, the issue of expectations arose only because, in the circumstances, the unjust factor consisted of free acceptance. Whereas most restitutionary claims traditionally turned on the

Supra note 5 at para. 57.

As when a person, without intending to confer a gif, knowingly provides an unsolicited and nonobligatory benefit.

As in the earlier example of the heated apartment: text accompanying supra note 52.

As when a person, without creating a contractual compromise and without intending to confer a gift. prefers to capitulate to a claim rather than litigate the matter immediatcly.

As when an adult provides non-essential services to a child pursuant to a contract that is avoided on the grounds of infancy. Although the adult can, in the circumstances, properly argue that the invalid contract cannot constitute a juristic reason for the enrichment, the availability of restitutionary relief would subvert the policy of protecting minors.

Al the first branch of Garland, lacobucci J.'s reference to other "valid common law, equitable or [other] statutory obligations" (supra note 5 at para. 44) is lifted verbatim from McLachlin J. 's earlier judgment in Peter, supra note 26 at 991.

Peter, ibid. Subsequent courts occasionally interpreted McLachlin J.'s statement to mean that restitution cannot be awarded unless it accords with the legitimalc or reasonable expectations that the partics had at the time of enrichment: Clarkson v. McCrossen (1995), 122 D.L.R. (4th) 239 at 25 I (B.C.C.A.); Canada (A.G.) v. Confederation Life Insurance (1995), 24 O.R. (3d) 717 at $771-72$ (Gen. Div.); Smithson v. Bock Estate (1998), 217 A.R. 50 at 66 (Q.B.); Ballman v. Melnitzer (Trustec of) (1996), 43 C.B.R. (3d) 33 at 42 (Ont. Gen. Div.); Re Colletl \& Brown Lid. (1996), II E.T.R. 164 at 179 (Ont. Gen. Div.); Regnier v. O'Reilly (1997), 39 B.C.L.R. (3d) 178 at 184 (S.C.); Greater Toronto Airports Authority v. Air Canada (1999), 99 O.T.C. 81 at para. 112 (Sup. Cl. J.); Campbell v. Campbell, supra note 28 at 794. It has also been suggested that the scope of relief ought to reflect legitimate expectations held not only by the parties, but also by the court and the public: Alberta Treasury Branch v. Baker Estate (2002), 7 Alta. L.R. (4th) 110 at paras. 98-101 (Q.B.).

Pestkus, supra note 1 at 849. 
plaintiff's impaired intention (as when a benefit was provided by mistake), the gist of Rosa Becker's complaint was that it was unconscionable for Lothar Pettkus to frustrate her expectation of sharing in the family assets.

Moving from precedent to principle, it becomes even more imperative for the courts to avoid, or at least carefully confine, references to the parties' reasonable expectations. To begin, such expectations are generally irrelevant to the availability of restitutionary relief. Consider the paradigm case of an unintended transfer. Restitution is triggered either by the fact that there was no basis for the defendant's benefit (on a juristic reason analysis) or by the fact that the plaintiff's intention was impaired (on an unjust factor analysis). Moreover, liability occurs at the time of transfer ${ }^{90}$ and without regard to the parties' knowledge. The right of recovery arises even if the plaintiff was wholly unaware of her loss (because the money was secretly taken from her by a third party) and even if the defendant was wholly unaware of his gain (because the third party secretly deposited the money into his account). And if both parties are initially oblivious to the transfer, then neither has, at the relevant moment, any expectation at all. At most, they may, after the fact, form the opinion that repayment is appropriate. Once informed of an unwarranted transfer, reasonable people usually believe that the courts ought to intervene. That is, however, a vacuous proposition. It simply states a conclusion reached on other grounds. Much the same could be said of every private law remedy, regardless of the cause of action.

The Supreme Court of Canada's focus on expectations also threatens to revive the "implied contract" theory that historically inhibited the development of a coherent principle of unjust enrichment. ${ }^{91}$ Justice Jacobucci's comments in Garland may be interpreted to mean that restitutionary rights, like contractual rights, positively arise from the parties' intentions. ${ }^{92}$ If so, there will be a temptation, in the absence of appropriate evidence, to either fictionally impute expectations to the parties or deny recovery. Of course, the better analogy for present purposes $^{93}$ lies not in contract, but rather in tort. Obligations in unjust enriclument do not arise from the parties' intentions. They are instead imposed by law, typically without regard to

As a result, limitation periods run, and interest accrues, from the time of transfer rather than from the time of the defendant's knowledge: Michelin Tires (Canada) Lid. v. Canada, [2001] 3 F.C. 552 (F.C.A.) [Michelin Tires] (assuming in dicta that commencement of the limitation period may be postponed pending discoverability by the plaintiff); Air Canada v. Ontarto (Liquor Control Board). [1997] 2 S.C.R. 581 (Liquor Control Board); Woolwich, supra nole 80. Sinclair v. Brougham, [1914] A.C. 398 (H.L.) [Sinclair].

42 In one sense, the danger arises more strongly from McLachlin J.'s view in Peter than from lacobucci $J$.'s view in Garland. Whereas he referred to the "reasonable expectarions of the parties" (plural) (supra note 5 at 46 [emphasis added]), she referred to the "legitinate expectation of the parties" (singular) (supra note 26 at 991). Accordingly, while there is a danger in parsing the language too finely, it might be argued that McLachlin J.'s "expectation" must be shared by both parties, as oecurs under a contract. Justice lacobucci's "expectations" may, in contrast, anticipate a difference of opinion.

Unjust enrichment is, of course, more akin to contract in another respect. Whereas liability in tort invariably presumes the breach of an obligation, restitutionary obligations and primary obligations in contract arise without fault. (In contract, however, the breach of a primary obligation constizutes a wrong. which may trigger a secondary obligation for remedial purposes. In unjust enrichment, there is only ever a primary obligation - the issue of wrongdoing never arises: Mclnnes. "The Measure of Restitution," supra note 6 at 188-93.) That is why Roman law referred to restitutionary obligations as "quasi-contractual" as opposed to "quasi-delictual." Unfortunately, the phrase quasi-contract was eventually misinterpreted to mean "sort of contract," thereby giving rise to the fiction of "implied contract." 
expectations and, indeed, sometimes in direct conflict with the only expectations that the parties actually entertained. ${ }^{94}$

The possibility of imputing expectations is dangerous not only because it facilitates the revival of the "implied contract" fallacy, but also because it is so easily manipulated in favour of desired results. Having formed an opinion as to an appropriate outcome, a judge may subconsciously collapse the distinction between what the parties ought to have expected and what they actually did expect. ${ }^{95}$ The temptation to read a case backwards may be especially powerful if, as often occurs, the parties had no real expectations at all.

The final concern is perhaps the most significant. There is a natural tendency to align causes of action and measures of relief. The law of contract is illustrative. Since the underlying institution is centrally concerned with an anticipated state of affairs, a successfu] claim for breach of promise usually culminates in an obligation to fulfill the relevant expectation. That is an entirely defensible position within contract. ${ }^{96}$ The same pattern of analysis has, however, spilled over into the action in unjust enrichment. Because the Supreme Court of Canada has analyzed the relevant relationship in terms of the parties' reasonable or legitimate expectations, it has occasionally quantified relief by reference to those expectations. ${ }^{\text {p7 }}$ That practice unfortunately ignores the fundamental differences that exist between the two areas of law. A contract is forward-looking. Its purpose is to allow the parties to confidently plan into the future, knowing that their expectations will be fulfilled, either directly or through the proxy of monetary relief. The plaintiff says to the defendant, "You promised to give me something - now give it." The law of unjust enrichment, in contrast, is backward-looking. It is based on "the Aristotelian notion of correcting a balance or equilibrium that has been disrupted." ${ }^{13}$ The gist of the claim is not that the plaintiff failed to receive an expected benefit, but rather that the defendant received a benefit to which he was not entitled. The plaintiff says to the defendant, "You got from me more than was appropriate - now give it back." In the circumstances, the only coherent response is restitution..$^{99}$

In a normal case of mutual mistake, for instance, both partics fully expect, at the time of payınent, that the transfer will be irreversible. To say that there is an implied expectation of repayment in the event of error is simply to create a tiction in order to achieve a particular result. The real reason for restitution is not the implied expectation, but rather the explanation underlying that fiction (i.e. the absence of any juristic reason for the enrichment or, more precisely, the fact that the plaintiffs intention to fulfill a purpose was vitiated by error). Nowell v. Town Estate (1997), 35 O.R. (3d) 415 (C.A.).

*. But see L.L. Fuller \& William R. Perdue, “The Reliance Interest in Contract Damages" (1936) 46 Yale L.J. 52.

97 That is particularly true in the cohabitational context: Petkus, supra note 1; Peter, supra note 26. Part of the explanation lies in the fact that the courts habitually rely upon the doctrine of free acceptance, which expressly refers to reasonable expectations. An even larger part of the explanation lies in the fact that the courts have recognized, at least implicitly, that restitution (properly defined) is an inadequate response in the circumstances. Parties typically view colhabitation as a type of partnership in which benetits and burdens are shared equally (though not necessarily in kind). To limit relief to the reversal of unwarranted transfers is to miss the whole point of the exercise. The underlying relationship requires a more expansive response. Notwithstanding current Canadian practice, however, the action in unjust enrichment cannot coherently fill that role.

w Mclnnes, "The Measure of Restilution," supra note 6. 


\section{(ii) The Proper Role of Expectations}

All of that is not to say that expectations are irrelevant to the action in unjust enrichment. The point, rather, is that they must not be approached at large. Like considerations of public policy, the parties' expectations must be addressed within the context of specific issues. A few examples will suffice.

Enrichments - Expectations are often important to the identification of enrichments. In some circumstances, a benefit may, by its very nature, be incontrovertible. Typically, however, the recipient will be considered enriched only to the extent that he assumed the risk of financial responsibility by either requesting or freely accepting a benefit. An important element in such cases is the defendant's knowledge of the plaintiffs expectation of payment. $^{100}$

Reasons for Restirution - Expectations may underlie the reason for restitution. A good example is provided by the concept of qualified intention (or failure of consideration), which traditionally served as an unjust factor and which will continue to play a role under the new regime of juristic reasons. While initially intending to effect a transfer, the plaintiff may premise the defendant's right to retain the benefit upon a future state of affairs. If that condition (expectation) is not met, the basis for the enrichment fails and the transaction is reversible.

Defences - Expectations may be relevant to defences. Change of position provides the best example. The defendant incurs an exceptional expenditure in reliance upon an enrichment. Liability will be reduced to the extent that the defendant incurred that expenditure without knowledge of the plaintiff's claim. In such circumstances, the defendant reasonably expected the expense to be borne by the apparent windfall, rather than by his preexisting resources. The court will respect that expectation. Restitution would otherwise adversely affect the defendant despite the fact that he had done nothing wrong. If, in contrast, the defendant incurred the expenditure with knowledge of the plaintiff s liability, the defence will not apply. The defendant cannot reasonably expect to place the burden of his expenditures on the plaintiffs.

Form of Relief - Finally, expectations may inform the court's choice of remedy. Restitution is the only measure of relief that is appropriate for the action in unjust enrichment. It may, however, take one of two forms. While the defendant usually becomes subject to a personal obligation to restore the value received, the plaintiff may, in exceptional circumstances, be entitled to a proprietary remedy, such as a constructive trust. The choice between personal and proprietary relief has never been fully explained. ${ }^{101} \mathrm{It}$ is clear, however, that the parties' expectations constitute an important consideration. ${ }^{102}$

McInnes, "Enrichments and Reasons for Restitution," supra notc 69

Robert Chambers, "Constructive Trusts in Canada" (1999) 37 Alta. L. Rev. 173; Robert Chambers,

"Resulting Trusts in Canada" (2000) 38 Alta. L. Rev. 378.

Sorochan, supra note 26. 


\section{WRONGDOING AND DISCRETION}

While not formally part of the new test of liability, two other aspects of the decision in Garland warrant brief discussion: (i) the relevance of wrongdoing, and (ii) the existence of an equitable discretion.

\section{A. STRICT LIABILITY AND FAULT}

The primary challenge facing the law of unjust enrichment lies in the need to balance the parties' competing interests. The plaintiff insists that she should be able to reverse a transfer that occurred without juristic reason. The defendant insists that he should be entitled to retain the wealth that is in his possession. In mediating a compromise between those interests, the courts must choose between two strategies.

The first strategy sets a high threshold to judicial intervention. Liability is fault-based. The defendant is allowed to retain an enrichment that was innocently received, even if, from the plaintiff's perspective, the transfer occurred without juristic reason. The plaintiff enjoys a right to recover, and the defendant incurs a duty to restore, only if the defendant acted wrongfully. The wrong consists of the defendant's decision to receive an enrichment despite knowledge that the transfer was defective or unwarranted.

The second strategy sets a lower threshold to judicial intervention. Liability is strict. The plaintiff prima facie is entitled to reverse any transfer that occurred without juristic reason, even if the defendant received the benefit innocently. The defendant is, however, strongly protected by defences. Most significantly, liability is reduced to the extent that he incurred an exceptional expenditure, in good faith, as a result of receiving the enrichment.

The relative merits of those two strategies can be seen in Garland. Between 1981 and 2001 , the defendant illegally collected late payment penalties (LPPs) from its customers. According to the court, the defendant had no reason to doubt its right to do so until 1994, when the plaintiff commenced his action. Restitution quite clearly was available with respect to money received after that time. For present purposes, however, the crucial question is whether the earlier payments ought to have been recoverable as well.

The fault-based strategy answers that question in the negative. The defendant cannot be held responsible for money that it innocently received. There is, however, a problem with that approach. It terminates the analysis too soon. At the time of transfer, the customers suffer a deprivation without juristic reason and the defendant acquires an enrichment as a result of its own criminal (albeit apparently permissible) activity. Moreover, the parties' respective positions presumably remain the same at the time of trial. The defendant has no need to demonstrate a change of position or otherwise deny that it continues to enjoy the ill-gotten gain. In order to establish a right to retain the enrichment, it merely had to show that it innocently received that benefit. In the absence of conscious wrongdoing, the law refuses to reverse the illegal windfall.

The source of the problem is obvious. The fault-based scheme fails to sensitively address the relevant concern. The danger with restitution is that, despite acting innocently, the 
defendant may be adversely affected by liability. The fault-based scheme, however, focuses exclusively on the first part of the equation. Innocent recipients are immune from liability, regardless of the actual effect of liability. The safety net is cast too wide. The defendant is relieved of responsibility even when there is no need for such protection.

The second strategy, in contrast, takes into account both the quality of the defendant's behaviour and the actual effect of liability. It provides protection only where it is needed. On that approach, the customers in Garland prima facie are entitled to relief upon proof that, given the illegality of the LPP scheme, there was an absence of any juristic reason for the enrichment. Since the apparent debt did not actually exist, the money was paid for a purpose that necessarily failed. Moreover, liability presumptively leaves the defendant none the worse for wear. Without proof to the contrary, it must be assumed that the defendant continues to enjoy the enrichment. ${ }^{103}$ It can therefore satisfy judgment, and restore the status quo ante, by simply returning that enrichment to the plaintiffs. The conclusion may be different only if the defendant experienced a change of position, such that it no longer enjoys a benefit with which to effect restitution. If that change of position occurred innocently, then the claim ultimately will fail because, despite doing nothing wrong, the defendant would be adversely affected by liability. ${ }^{104}$ If, however, the defendant voluntarily sustained the change of position despite knowledge of the plaintiffs' claim, the defence will be denied. The defendant cannot escape responsibility for its decision to incur the exceptional expenditure. Although liability will create a net loss, the defendant has only itself to blame.

Although the second strategy is clearly preferable, the court in Garland adopted the first. As previously explained, lacobucci J. held: (i) that payments made prior to 1994 were irrecoverable because the defendant had honestly received them in reliance upon the OEB orders, and (ii) that payments received after the plaintiff commenced the action prima facie were recoverable, and that the defendant's knowledge of the claim precluded the plea of change of position.

I'I It is sufficient that the enrichment survives abstractly. Restitution is generally required personally rather than proprictarily. Consequently, as long as the defendant's wealth continues to be enhanced by the initial receipt, it is irrelevant that it no longer holds the enrichment in specie. Suppose, for instance, that the plaintiff mistakenly gives a $\$ 100$ bill to the defendant. The defendant puts that money into his pocket, alongside another $\$ 100$ that he intended to spend on a massage. Later in the day, he actually pays the masseuse with the bill received from the plaintiff. The enrichment is no longer recoverable in specie (assuming that the masseuse was a bona fide purchaser for value without notice), but the defendant remains abstractly enriched. He has $\$ 100$ more, and the plaintiff has $\$ 100$ less, than is appropriate. The court should impose a personal obligation to provide restitution. See Peter Birks, "Change of Position: The Nature of the Defence and Its Relationship to Other Restitutionary Defences" in Mitchell Mclnnes, ed. Restitution: Developments in Unjust Enrichmem! (Sydney. L.BC Information Services, 1996) c. 3.

in That may, in fact, have been true on the facts of Garland. There was evidence to suggest that if the defendant had not relied upon the apparent validity of the LPP scheme, it would have received OEB approval for a different configuration of the same overall revenue stream. In other words, if it had not received the disputed amounts as late payment penalties, it would have received them as, say, part of the basic price. Although that form of change of position has not yet been formally recognized by Canadian courts, it appears to be sound in principle. The Privy Council recently recognized the relevance of anticipatory changes of position in Dextra Bank, supra note 72. 
The effect of those decisions is not, however, entirely clear. They might be taken to mean that restitution is never available with respect to innocently acquired enrichments. Alternatively, they might be confined, for reasons that were not made entirely clear, to the special circumstances of Garland. In addition to the preceding arguments, two points can be offered in support of the latter interpretation:

A Malter of Precedent - Seven years before Garland, lacobucci J. addressed a very similar situation in Liquor Control Board. ${ }^{105}$ In that case, he conceded that a rule premising liability upon the defendant's knowledge may seem to be a "compromise" with a "a certain "equitable appeal." 106 Ultimately, however, he rejected such an approach as "arbitrary." It is difficult to believe that the judge simply forgot about his earlier decision. It must be assumed that he perceived some distinction between the two cases and that, notwithstanding his fault-based analysis in Garland, he believed that restitutionary liability is, at least occasionally, strict.

A Matter of Principle - While denying the defence on the facts of Garland, lacobucci $\mathrm{J}$. clearly saw some role for the plea of change of position. But because that defence requires proof that the defendant incurred an exceptional expenditure in good faith, it does not make much sense within a fault-based regime. ${ }^{107} \mathrm{Garland}$ itself is illustrative. The defence became relevant at precisely the same moment that it became inapplicable. ${ }^{108}$ Upon learning of the plaintiff's claim, the defendant became fixed with knowledge that was sufficient to: (i) facilitate a right of recovery, and (ii) preclude the sort of innocent expenditure that is required for a change of position. It is, however, difficult to believe that the Supreme Court of Canada would generally subscribe to two irreconcilable propositions. In supporting the defence of change of position, lacobucci J. must have intended to confine his theory of fault-based liability to the particular circumstances of Garland.

\section{B. Equitable Discretion}

The Court's decision to premise liability upon proof of the defendant's wrongdoing is anomalous. It is contrary to precedent and principle, and it should not generally affect the action in unjust enrichment. The final point to emerge from Garland cannot be so easily dismissed. Justice Iacobucci said that restitution "is an equitable remedy that will necessarily

Supra note 90. But see Cisadel, supra note 27.

Liquor Control Board, ibid. at para. 80.

107

In theory, there might be a difference between the sort of fault that triggers liability and the sort of fault that precludes change of position. Justice lacobucci described the former in terms of the defendant's "actual or constructive notice" of the transfer's defect (supra note 5 at para. 58 [emphasis added]). Although he did not discuss the elements of the defence in detail, it may be, at least in some cases, that change of position is available as long as the defendant did not have actual knowledge of the plaintiffs interest: Jones, Goff \& Jones: The Law of Restitution, supra note 56 at 833 . Canadian courts have not, however, been inclined to draw such fine distinctions.

10* The defence is often said to be barred by either wrongdoing or bad faith: RBC Dominion Securities Inc. v. Dawson (1994), 114 NAld. \& P.E.I.R. 187 at 192 (Nfld. C.A.). Justice lacobucci focused on the former. The defendant was unable to plead change of position because it received its enrichment illegally. However, even if that element of impropriety had been absent, the defence would have been barred, during the relevant period, by the defendant's knowledge of the plaintiff s claim. 
involve discretion and questions of faimess." 109 That, unfortunately, is a common view within Canada. ${ }^{130}$

The first part of lacobucci J.'s statement is simply wrong. Restitution is not normally an "equitable remedy." Its roots lie primarily in the ancient action for money had and received,"' which was a form of indebilatus assumpsit, which in turn was a form of assumpsit, which in turn was a form of the action on the case. Each instance of the claim, from species to genus, arose in law rather than equity. The leading case of Moses ${ }^{\prime \prime 2}$ was decided by a common law judge (Lord Mansfield) in a common law court (King's Bench). Consequently, as Canadian courts have occasionally recognized, ${ }^{113}$ unjust enrichment "is a perfectly legal action." 114 True to its historical origins, equity becomes involved only if there is something in the circumstances to pique the chancellor's interest. That may be true, for instance, if a transfer occurred within the context of a relationship that exists only in equity (as when a stranger receives misdirected trust funds) ${ }^{115}$ or if a dispute requires a remedy that

Supra note 5 at para. 44. The judgment contains repeated relerences to "equity" and the need for "nexibility."

In British Columbia v. Canadian Forest Products Lid., LelBel J. cited Garland and referred to the flexible "equitable analysis" that is "omnipresent in the law of restitution": 2004 SCC 38 at para. 199. See also Dominion Bank v. Union Bank of Canada (1908), 40 S.C.R. 366 at 381 ; Srorthoaks, supra note 14 at 158-64: Pettkus, supra note I at 847-49; Air Canada, supra note II at 1212; Peter, supra note 26 at 986-87; Campbell, supra note 28 at 791; Bruyninckx v. Bruminckx, [1995] 5 W.W.R. 683 (B.C.C.A.): Morgan Guaranty Trust Co. of New York v. Outerbridge (1990), 72 O.R. (2d) 16] (H.C.J.).

III Money had and received was one of the "common counts" that arose under indebitatus assumpsis. Among the others were the actions for money paid, quantum meruis and quantum valebat. Supra note 20. Part of the confusion stems from the fact that Lord Mansfield "never liked Law so well as when it was like Equity" (Lord Dursley v. Fitzhardinge Berkeley' (1801). 31 E.R. 1036 at 1041 (Ch.)). That proposition is evidenced by his tendency to analogize between law and equity on procedural issues. And for that reason, he found the action for money had and received to be especially attractive. In contrast to other common law writs, but like bills in equity, it did not require the plaintiff to plead with great specificity and, by corollary, allowed the defendant to raise every defence on the general issuc: S.J. Stoljar, The Law of Quasi-Contract, 2nd ed. (Sydney: Law Book Co., 1989) at 14-15; John H. Baker, An Introduction to English Legal History. 4th ed. (l.ondon: Butterworths, 2002) at 37576; Cecil H.S. Fifoot, Lord Mansfield (Oxford: Clarendon Press, 1936) at 149-50. Lord Mansfield's enthusiasm for equitable analogies was shared, even more strongly, by Buller J., who sat as a puisne judge on the same bench: Straton v. Rastall (1788). 100 E.R. 197 at 199 (K.B.): William S. Holdsworth, A History of English Lant, vol. Xil, 2d ed. (London: Methuen \& Co.. 1938) at 542-49. Another strand of confusion stems from Lord Mansfield's desire to draw upon Roman law roots in order to provide a generalized explanation for the nature and scope of the claim. In English law, as in Roman law, the basic reason for restitution, when extrapolated from the cases, consisted of "reasoned fairness" (equitas). That is what he meant when he said that the action for money had and received was "founded on the equity of the plaintifrs case," "lies only for money which, ex aquo et bono, the defendant ought to refund" and creates an obligation "by the ties of natural justice and equity' to refund" (Moser, supra note 20 at 678, 680 and 681). Unfortunately, taken out of context, those statements appear to support the proposition that restitution "is an equitable remedy." See Carter \& Tolhurst, "Case Comment: Roxborough v. Rothmans of Pall Mall," supra note 75 at 296: Robert $\Lambda$. Samek, "Unjust Enrichment. Quasi-Contract and Restitution" (1969) 47 Can. Bar. Rev. I at 15-17; Jolin P. Dawson, Unjusst Enrichment: A Comparative Analysis (Boston: L.ittle Brown \& Co., 195I) all 14. at 454-56; Baylis v. Bishop, [1913] I Ch. 127 at 137 (C.A.): (hapman v. Forbes (1890), 26 N.E. 3 at 4 (N.Y. C.A.). 
is unknown to law (as when restitution is ordered proprietarily in the form of a constructive trust)..$^{116}$

Relatively innocuous in itself, ${ }^{117}$ the initial historical error becomes deeply troubling when coupled with the belief that equitable principles "necessarily involve discretion and questions of faimess." While the chancellor, as repository of the king's residuum of justice, originally enjoyed authority to resolve disputes on the basis of conscience, equity had, by the time of Lord Eldon, ${ }^{118}$ settled into a system of fixed rules and binding precedent. Two centuries later, there is no need to regress. 19

Unjust enrichment is, admittedly, a difficult subject precisely because it requires the courts to consistently strike an appropriate balance between competing interests. And because the circumstances may vary greatly from one case to the next, there is a temptation to eschew rules in favour of intuition. For fear of establishing a doctrine that might occasionally create hardship, it might be thought desirable to leave the resolution of each dispute to the discretion of the judge.

That conclusion would, however, be hard to accept even if, as the argument assumes, it was impossible to identify and address the relevant concerns in advance. A broad discretion sits uneasily alongside the rule of law. A litigant should never be forced to hear a judge say, as a substantial reason for judgment, "This is what I think is fair." Anyone can provide a personal opinion, the judge no better than the plumber or the poet. People go to court legitimately expecting judges to apply rules.

Penkus, supra note I. Significanily, even if the remedy is equitable, the underlying action may be legal. The tort of trespass remains a common law claim even when the chancellor, acting in his auxiliary jurisdiction, restrains it through injunction. Likewise, unjust enrichment typically retains its legal character even if it attracts an equitable trust.

i' The parties are sometimes adversely affected by the historical error per se. For instance, Canadian courts have occasionally held that if they are statutorily incapable of awarding "equitable relief," they cannot entertain actions in unjust enrichment: Caranci v. Ford Credit Canada Leasing Limited (14 November 2002), London, Ont. Docket No. 1280 at para. I (Ont. Div. Ct.); but see Prtenjaca (c.o.b. Pro Drywall 509539 Ontario Lid.) v. Fox (2001), 9 C.L.R. (3d) 141 (Ont. Sup. Ct. J.); 936464 Ontario Lid. (c.o.b. Plumbhouse Plumbing \& Ifeating) v. Mungo Bear Ltd., [2003] O.J. No. 3785 at para. 9-19 (Ont. Div. Ct.) (QI.). So too, they have occasionally held that since "[u]njust enrichment is an equitable remedy," it is subject to the equitable bar of clean hands, such that the "party claiming it must establish that its conduct leading to its deprivation was untainted": Toronto-Dominion Bank v. Bank of Montreal (1995), 22 O.R. (3d) 362 at 373 (Gen. Div.); but see Kelly v. Solari (1841), 152 E.R. 24 (Ex. Ct.); Dixdale, supra note 48 at $\$ 19$.

"Nothing would inflict on me greater pain in quitting this place, than the recollection that I had done any thing to justify the reproach that the equity of this Court varies like the Chancellor's foot" (Gee $v$. Pritchard (1818), 36 E.R. 670 at 674 (Ch.)).

(11) Chief Justice McLaclalin has repeatedly rejected the suggestion that recovery can be awarded on the basis of justice and fairness alone and she has cautioned against the tendency to view the action for unjust enriclıment as a device for doing whatever may seem fair between the parties: Peel, supra note 23 at 802; Peter, supra note 26 at 987-88. Lord Goff has similarly explained that "restitution is not, as a general rule, a matter of discretion for the coun. A claim to recover money al common law is made as a matter of right: and even though the underlying principle of recovery is the principle of unjust enrichment, nevertheless, where recovery is denied, it is denied on the basis of legal principle" (Lipkin. supra note 50 at 578). See also Pavey \& Mathews Po. Ltd. v. Paul (1987), 162 C.L.R. 221 at 256 (H.C.A.), Deane J. (denying that the principle of unjust enrichment creates a "judicial discretion to do whatever idiosyncratic notions of what is fair and just night dictate"). 
In fact, however, the underlying assumption is not correct. There is nothing inherently unpredictable in the law of unjust enrichment. Given the structure of the claim, the parties' interests consistently manifest themselves in recurring patterns. Moreover, as demonstrated by the remarkable body of literature that has been created in recent decades, and as suggested in this article, it is possible, without running the risk of unfaimess, to resolve those concerns on the basis of fixed rules. There is no need to leave anything to chance. Since restitution merely restores the status quo ante, it should be available, subject to well-defined qualifications, whenever the defendant continues to be abstractly enriched as a result of a transfer that occurred without juristic reason.

\section{CONClusion}

Unjust enrichment stands at a crossroad. ${ }^{120}$ For better or worse, the Supreme Court of Canada has abandoned the common law tradition and charted an essentially civilian course. That change in direction is profound. While frequently arriving at the same destination, unjust factors and juristic reasons take very different paths. And because the new landscape will be unfamiliar, there will be a temptation to turn back. That urge must be resisted. Every effort must be directed instead toward mapping the new terrain.

Literally interpreted, however, Garland is unworkable. The core concepts have been correctly identified, but they need to be slightly restructured. The plaintiff must bear responsibility for showing that an enrichment occurred without juristic reason. The defendant must bear responsibility for showing that, notwithstanding the existence of a prima facie claim, restitution ought to be reduced or denied on the basis of a defence. Public policy and reasonable expectations are important considerations, but they must be examined in the context of specific concerns. The action in unjust enrichment must not degenerate into an ad hoc exercise in equitable discretion. Nor should liability generally be premised upon a finding of fault.

13: To borrow an image from 'Thonas Krebs, Restitution at the Crossroads: A Comparative Study (I.ondon: Cavendish, 2001). Interestingly, shortly before the Supreme Cour of Canada unequivocally adopted a civilian model, Professor Birks insisted that English law had done likewise: Unust Enrichment, supra note 49. The House of Lords has not, however, produced anything in the nature of Garland and it remains to be seen whether Birk's' conclusion, based on a series of inferences and arguments, is correct. 